\title{
Digital Narration: The Pictures in School Books as a Source of Inspiration and Artistic Creation
}

\author{
Maravelaki Sofronia \\ Department of Philosophy, Faculty of French Language and Literature, Sector of Language Teaching and New Technologies in Language \\ Communication, Aristotle University of Thessaloniki, Thessaloniki, Greece
}

\section{Email address:}

maravelas@frl.auth.gr

To cite this article:

Maravelaki Sofronia. Digital Narration: The Pictures in School Books as a Source of Inspiration and Artistic Creation. Psychology and Behavioral Sciences. Vol. 8, No. 5, 2019, pp. 133-137. doi: 10.11648/j.pbs.20190805.15

Received: June 25, 2019; Accepted: August 3, 2019; Published: October 23, 2019

\begin{abstract}
The present article describes a Cultural Program of Extra Curricular School Activities which took place during the school year 2017-18, at a Junior High School located in North Greece. The program with the title "Digital Narration" concerned the creation of digital stories by the students of the $7^{\text {th }}$ grade. The digital stories took part in the $5^{\text {th }}$ International Student Competition, co-organized by the Museum of School Life and Education, of the National Centre of Research and Preservation of School Material, and of the Department of Educational Radio-Television and Digital Media, under the auspices of the Greek Ministry of Education. The topic of the contest was the pictures in school books which provided a source of inspiration and of artistic creation to the students and gave them the opportunity to develop $21^{\text {st }}$ century skills and competences. The students' digital stories won first prize in the competition and the overall program received an Honorary Diploma from the Serres Group for Unesco, as it supported "Quality Education", the $4^{\text {th }}$ sustainable development goal.
\end{abstract}

Keywords: Digital Storytelling, Extra Curricular School Activities, Unesco, Sustainable Development Goals, $21^{\text {st }}$ Century Skills

\section{Introduction}

The Programs of Extra Curricular School Activities (PECSA) aim at the formation of active, critically thinking and creative citizens. The pedagogical principles that underlie those programs are student centered teaching and learning, experiential learning, discovery learning, interdisciplinary and / or cross curricular principles, free and creative expression [1]. Respectively, the methodological approaches adopted by these programs are Project Based Learning (PBL), case studies, role playing, simulations, action research and ethnography [2]. PECSA consist of Environmental, Health, Cultural and Career Education programs and are implemented by Primary and Secondary Schools in Greece. Cultural education programs are, according to the Ministry of Education [1], a creative procedure aiming at the promotion of cultural heritage and the cultivation of the participants' artistic qualities through research, study and creation.

UNESCO's 17 sustainable development goals until 2030 are included for the first time in this year's circular [3]. The $4^{\text {th }}$ goal refers to "Quality Education". Education is the process of facilitating learning or the acquisition of knowledge, skills, values, beliefs and habits. Quality education specifically entails issues such as appropriate skills development, gender parity, provision of relevant school infrastructure, equipment, educational materials and resources, scholarships or teaching force [4]. In addition, ICT Literacy skills such as web page creation, digital stories, digital games and digital art, are some of the suggested topics which are included in the PECSA.

In the context of the above programs, a cultural program was implemented at Iraklia's Junior High School with the title "Digital Narration" during the school year 2017-18. The program was inspired by the $5^{\text {th }}$ International Student Competition co-organized by the Museum of School Life and Education, of the National Centre of Research and Preservation of School Material, and of the Department of Educational Radio-Television and Digital Media, under the auspices of the Greek Ministry of Education [5]. The title of the competition was "The pictures in school books as a source 
of inspiration and artistic creation" and the topic was the magical world of the pictures inside the books, the illustrations and the covers, which would act as the stimulus for the production of audiovisual material, comics, animation, storytelling, creative writing, photostories, radio broadcasts, and other artistic creations. The goals of the competition were the following:

a) Strengthening the audiovisual literacy skills of students through critical viewing processes and production of audiovisual material.

b) Encouraging students to participate in research projects and cooperative learning activities.

c) Collecting, preserving, classifying and viewing primary and secondary sources from the field of education (obsolete books).

d) Manifesting a critical convergent attitude.

e) Manifesting a creative divergent attitude.

f) Design and implementation of creative writing activities through the use of images.

g) Description of experiences concerning school programs and activities.

h) Active participation of students in the learning processes.

In order to participate in the competition, the students had to choose one out of two projects. In the first project they had to choose a book cover or a series of pictures from the illustrations of a book. These would serve as the incentive to create a written narration. In continuation, they would use the narration to create the script and the storyboard of their narration in order to produce one of the following:

a) Comic.

b) Animation.

c) Digital narrative.

d) Photostory.

e) Photobook.

f) Painting.

In the second project they had to use an existing book cover or create one from scratch in order to take part in the International Competition of School Book Covers, and represent Greece, by using one of the following:

a) A TV commercial.

b) A radio commercial.

c) A printed Poster.

The program took into consideration the students' needs and interests, a fact that guaranteed their active engagement and participation, the groups' coherence and the project's successful implementation. According to Cassells et al [6], in Europe, $75 \%$ of the students are occupied with digital activities. Marc Prensky [7] had called the new generation "digital natives" since 2001, because they had grown up surrounded by technology. Of course, even though they started as simple consumers of technology, young people today have also got the opportunity to become creators of digital content. In addition to practicing technical skills involving computer use, the creation of digital narratives gave students the chance to practice and develop $21^{\text {st }}$ century skills, as well as audiovisual and organizational skills [8].

\section{Theoretical Background and Methodology}

The design and implementation of a cultural PECSA program is based on constructivist approaches for teaching and learning. Constructivism introduced open and student-centered models of teaching, highlighted the importance of collaborative teaching and supported exploratory, discovery, situated, cooperative and autonomous learning [9]. In the above context, $21^{\text {st }}$ century skills can be developed as they demand modern learning environments which are based on innovative pedagogical approaches like cooperative and exploratory learning and problem solving [10].

Digital storytelling as a teaching method is the process of creating short digital stories which enable students to develop competencies such as researching and collecting information, problem solving skills and at the same time to strengthen their ability to work in groups [11]. We believe that the theoretical background of the program "Digital Narration" constitutes the convergence of the above mentioned pedagogical principles and approaches. The PBL methodology was adopted for the planning and implementation of the program and consisted of the following stages: Preparation, Implementation and Evaluation, stages that coincide with the planning and implementation of a PECSA program as suggested by the Greek Ministry of Education (Table 1).

Table 1. Stages of implementing a PECSA program.

\begin{tabular}{ll}
\hline 1 & Selecting topic and sub topics \\
2 & Determining the main goal and the additional goals \\
3 & $\begin{array}{l}\text { Group formation } \\
4\end{array}$ \\
5 & $\begin{array}{l}\text { Researching and collecting information and materials } \\
\text { of conclusions }\end{array}$ \\
6 & Production and presentation \\
\hline
\end{tabular}

Jakes \& Brennan [12] suggest a procedure for creating short digital stories which was incorporated into the PBL methodology (Table 2). It is worth mentioning that PBL is recognized by researchers as a means of developing $21^{\text {st }}$ century skills to students [13].

Table 2. Digital story production procedure.

\begin{tabular}{ll}
\hline Step 1 & Write \\
Step 2 & Develop script \\
Step 3 & Storyboard \\
Step 4 & Locate resources \\
Step 5 & Create \\
Step 6 & Share \\
\hline
\end{tabular}

\subsection{Preparation}

The program was held twice a week, Monday and Tuesday morning and the meetings took place during the $6^{\text {th }}$ and $7^{\text {th }}$ periods, which were designated as the official time slots in the school's timetable for the implementation of the program. The participants were 40 students of the $7^{\text {th }}$ grade, 20 students from 
class A1 and 20 students from class A2 and it took 25 teaching periods for the program to implement in each class. The preparation stage included the design of the program and it took 11 teaching periods to complete.

In the first meeting the students were acquainted and familiarized with what digital storytelling is and what the types of digital stories are (Appendix I) [14]. In the second meeting the students watched short digital stories of various topics and themes as examples, in order to consolidate the theoretical framework presented to them in the first meeting. Later they were presented with the topic of the contest in which they expressed eagerly their enthusiasm to participate. In the next 4 meetings the main goal and the additional aims of the program were determined, the students formed groups and they selected the topic of their story. The preparation stage included the signing of a contract among the members of the teams, which had the form of a poster with a mandala design, in order to ensure collaborative attitudes among them (Figure 1).
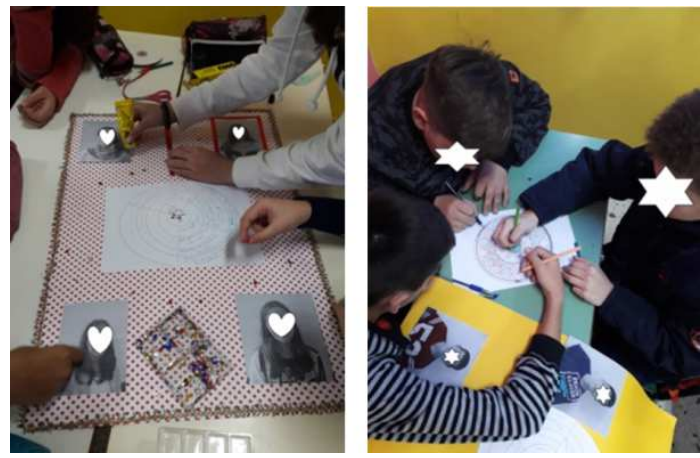

Figure 1. De-signing contracts.

The main goal of the program was the creation of a digital story by each team and the participation in the contest. The additional aims of the program were:

a) $21^{\text {st }}$ century skills development (creativity, critical thinking, collaboration, communication).

b) Artistic skills development.

c) ICT literacy skills development.

In the following meetings the students wrote the story (Figure 2). Each team was given printed material with the seven elements of digital storytelling, the steps of creating a digital story and some useful tips in order to help students in the creation of the digital story (Appendix II) [15].
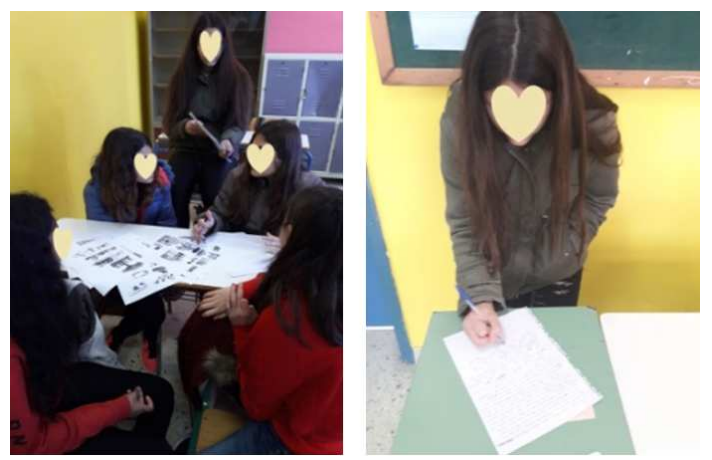

Figure 2. Story writing.
The next step was to give the students the printed pictures of the book "Alfavitario", an obsolete reading book for the first grade of primary school which is now considered a book of historical and educational heritage, as it was edited in 1965 and taught many generations of Greek students their first words. The book was reprinted as a reminder of the old times [16]. During the next 2 meetings the students created the storyboard of their story using those pictures from the book which best fitted the topic of their story (Figure 3).
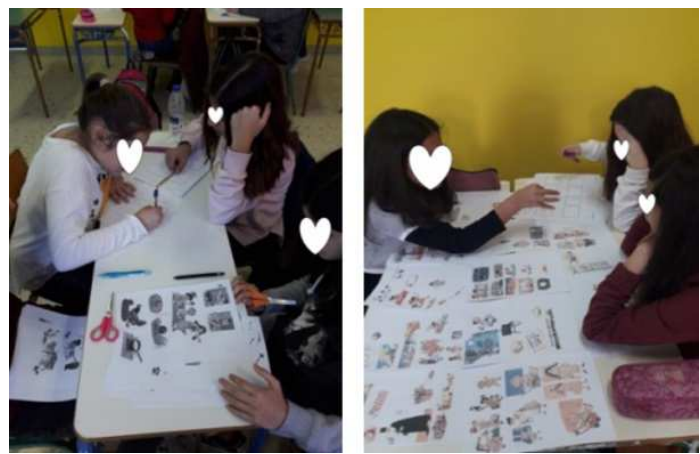

Figure 3. Storyboarding.

\subsection{Implementation}

The implementation stage lasted 10 periods and consisted of the creation of the digital story at the computer laboratory, the recording of the students' voices narrating their story and inserting the narration into the digital stories at the computers (Figure 4). During this stage the teams were assisted by the educator or by other team members who were familiar with the software as they did not receive instruction in the use of the video creation software. The software which was used for the video production was the Microsoft Photo Editor for Windows 10.

This software was chosen because it is incorporated in the windows system of the computers and it is also very easy to use, as the pictures are added to a picture folder and the software creates automatically a video out of the exact same folder. The students had to change the order of the pictures, format the text, choose the effects and the length of their story and add the music from the themes offered by the software. In order to add the recorded narration to the digital story, the software Movie Maker was used as the Microsoft Photo Editor for Windows 10 does not offer two channels for adding music and recorded voice at the same time. Each digital story was extracted in the form of an mp4 archive from the Microsoft Photo Editor for Windows 10 and was edited in the Microsoft Movie Maker with the addition of the recorded narration.

The students created digital stories inspired by their own experiences and prior knowledge. They developed the strength of their voice and became the heroes of their own love stories, horror stories, personal wagers and anxieties. Digital storytelling was used more as a means of personal expression, an outlet of suppressed emotions, a self-discharge rather than as a production of educational material, though the digital stories could constitute examples of creative expression for other students. 


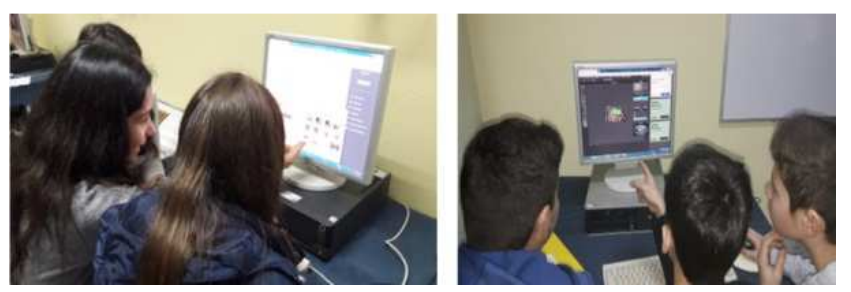

Figure 4. Digital story creation at the computer lab.

\subsection{Evaluation}

The evaluation stage lasted 4 teaching periods and included the evaluation of the digital stories by the educator and by the students themselves (self-evaluation). Each group evaluated their own product according to a rubric. The same rubric was used for the evaluation by the educator and for the peer evaluation between groups (Appendix III) [17]. After the evaluation and the subsequent revisions, the stories were sent to the competition. In the context of the self-evaluation, a questionnaire was administered to the students which researched the development of collaborative and communication skills among group members. The students filled in the online questionnaire (Google form) and the results revealed the high degree of the students' collaboration and communication during the program (Appendix IV) [18].

In the end, each group presented their digital story at the end of year celebration at the school premises. Except from the achievement in the competition, the program received an honorary diploma by Unesco, Serres, for supporting the $4^{\text {th }}$ sustainable goal development, "Quality Education", as a final form of evaluation. Information about the digital storytelling program can be accessed to the website "Digital Storytelling" created for this purpose with the web 2.0 tool "Wix" (https://frynimarvel.wixsite.com/digitalstorytelling) and the digital stories can be seen at the site's page Projects (https://frynimarvel.wixsite.com/digitalstorytelling/oi-eikone s-ton-sxolikon-vivlion).

\section{Conclusions}

Generally it can be asserted that the program achieved the goals to a satisfactory degree. 9 out of the 12 groups that participated in the program produced digital stories which were evaluated and judged as suitable to take part in the competition. The rest of the teams did not manage to record their narration and insert it in the digital story in order to edit it with the Movie Maker. Factors like loss of teaching periods because of excursions, national holidays or team members being absent made the whole process difficult to complete. Nevertheless, students collaborated very well with each other and managed to communicate their messages successfully.

They also created digital products using their inspiration and imagination and thought critically of every step of the process, actions which comprise the basic elements of critical and creative thinking. They took the initiative, they made decisions and they participated actively in the construction of their digital story. Moreover, as Paleochorinou [02] declares, the added value of a cultural PECSA program lies in the capitalization and enrichment of the cultural asset of all the participants and stakeholders in these programs, in the cultivation of positive attitudes and behaviors, in the broadening of the cognitive and the spiritual mind and in the contribution and promotion of the creative powers of culture and education.

It also deserves to be mentioned that the students, as well as students from other classes, manifested their interest in creating more digital stories. This way, digital storytelling was added as a special extracurricular subject at the school's annual programming for the educational activities of the next school year.

\section{References}

[1] Ministry of Education - (2017). Programs of Extra Curricular School Activities (PECSA), at bit.ly/2piAPPG.

[2] Paleochorinou, P. (2018). The school as a place of production and communication of culture: Cultural programs at the secondary education department of East Thessaloniki. Unpublished Master's Thesis. Thessaloniki: HOU.

[3] UNESCO's 17 sustainable development goals until 2030, at https://en.unesco.org/sdgs.

[4] SDG Resources for Educators - Quality Education, at https://en.unesco.org/themes/education/sdgs/material/04.

[5] Circular (2017). The pictures in school books as a source of inspiration and artistic creation, at http://www.ekedisy.gr/mathitikoidiagonismoi/.

[6] Cassells, D., Gilleran, A., Morvan, C. \& Scimeca, S. (2016). Growing digital citizens. Developing active citizenship through eTwinning. Belgium: Central Support Service for eTwinning, athttps://www.etwinning.net/eun-files/book2016/EN_eTwinni ngBook.pdf.

[7] Prensky, M. (2001). Do they really think differently? On the Horizon, 9/6: 1-9, at http://www.marcprensky.com/writing/Prensky\%20-\%20Digita 1\%20Natives,\%20Digital\%20Immigrants\%20-\%20Part2.pdf.

[8] Porter, B. (2009). Digital storytelling in the classroom. Tech4Learning, http://www.digitales.us/wp-content/uploads/2015/07/Digital_S torytelling_in_the_Classroom.pdf.

[9] Maragos, Ch., Nakis, I., Davlantis, I. \& Strataki, K. (2002). Learning theories and their pedagogical contribution. University of Athens, B Level of ICT Education and Training.

[10] Petropoulou, O., Kasimati, A., Retalis, S.. (2015). Concept and Content of Educational Assessment in the 21st Century. In O. Petropoulou, A. Kasimati \& S. Retalis, Contemporary forms of educational evaluation with the use of educational technologies. Athens: Association of Greek Academic Libraries, at http://hdl.handle.net/11419/233Y.

[11] Robin, B. (2008). Digital storytelling: A powerful technology tool for the 21 st century classroom. Theory into Practice, $47 / 3$ : 220-228,

at http://digitalstorytellingclass.pbworks.com/f/Digital+Storytelli ng + A + Powerful.pdf. 
[12] Jakes, D. S. \& Brennan, J. (2005). Capturing stories, capturing lives: An introduction to digital storytelling, at http://www.jakesonline.org/dst_techforum.pdf.

[13] Bell, S. (2010). Project-based learning for the 21st century: Skills for the future. The Clearing House, 83/3: 39-43, at http://bie.org/object/document/skills_for_the_future.

[14] Appendix 1. Mitsikopoulou, B. (2014). English and Digital Literacies. Introduction to Digital Storytelling. Edition: 1.0. Copyright National and Kapodistrian University of Athens, at http://opencourses.uoa.gr/courses/ENL10/.

[15] Appendix 2. Mitsikopoulou, B. (2014). English and Digital Literacies. How to Develop a Digital Story - Procedure and
Tools. Edition: 1.0. Copyright National and Kapodistrian University of Athens, http://opencourses.uoa.gr/courses/ENL10/.

[16] Yiannelis, I. \& Sakkas, G. (2004). Alfavitario. Athens: Kalokathi Publications.

[17] Appendix 3. Digital Storytelling Rubric, from Scott County Schools, Kentucky as published on RubiStar, at https://electronicportfolios.com/digistory/DS-rubric.pdf.

[18] Appendix 4. Evaluating collaborative and communicative skills during group work. 